\title{
A Case of XX Male Syndrome
}

\section{RUBÉN LISKER, FERNANDO FLORES, AZYADÉH COBO, and FERNANDO GARCIA ROJAS}

\author{
From the Departments of Genetics, Endocrinology, and Pathology, Instituto Nacional de la Nutrición, Dr. Fimenéz
} No. 261, México 7, D.F.

At least 10 instances of $\mathrm{XX}$ males have been published (de la Chapelle et al., 1964, 1965; Court Brown et al., 1964; Therkelsen, 1964; Strauch et al., 1965; Lindsten et al., 1966; von Mulert, Schröter, and Wolf, 1966; Zuppinger et al., 1967; Grouchy et al., 1967). They are characterized by having a fairly normal male phenotype with a female sex chromosome constitution and are an important exception to the general belief that, in man, the presence of the $\mathrm{Y}$ chromosome is necessary for testicular development. Their clinical, hormonal, and histological characteristics are uniform enough, so that it is possible to speak of the XX male syndrome as a clinical entity.

The present report deals with a patient showing most of the abnormalities of the above syndrome but who, contrary to other cases, has led an apparently normal life.

\section{Case History}

A 37-year-old white man was first seen in our Institution at age 25 . He complained of epigastric distress, accompanied by other symptomatology suggestive of peptic ulcer. Upper gastro-intestinal series showed only antral gastritis and he was discharged with proper medication. Twelve years later he was seen again because of rectal complaints due to the presence of large internal haemorrhoids which were treated surgically. At this time it was noticed he had been married twice without any offspring, and his physician decided to study him because of sterility.

He began puberty at 14, with the appearance of libido, normal hair growth on the face, axillae, and pubis, and deepening of the voice. He stated that his first sexual contact occurred when he was 15 and that erection as well as the amount of the ejaculate were normal. According to him and his second wife, he enjoys normal sexual relations.

Physical examination reveals a normal male phenotype (Fig. 1) with an android distribution of body hair with heavy beard and moustache. Height $1.59 \mathrm{~m}$.,

Received 20 January 1970. upper segment $82 \mathrm{~cm}$., lower segment $77 \mathrm{~cm}$., arm span $1.74 \mathrm{~m}$., weight $67.4 \mathrm{~kg}$. The penis measures $5 \mathrm{~cm}$. and has a normal width. Both testicles are smaller than normal, measuring $1.5 \mathrm{~cm} . \times 1 \mathrm{~cm}$., the left one being in its normal position while the right one is located at the external orifice of the inguinal canal. The prostate gland is smaller than normal.

Spermatobioscopy revealed complete azoospermia. Biopsy of the testicles showed severe histological abnormalities (Fig. 2 and 3). The seminiferous tubules were reduced in number and difficult to recognize because of the inter- and intratubular fibrosis. The lumen was completely obliterated but a few undifferentiated cells, of the germinal type, can be seen. Some of the latter are suggestive but not characteristic of Sertoli cells; there is no evidence of spermatogenesis. Some of the cells present in the intertubular tissue could correspond to degenerate Leydig cells. The diagnosis was diffuse interstitial and tubular fibrosis with complete azoospermia. The urinary 24-hour excretion of 17-ketosteroids was 4.3 and $6.6 \mathrm{mg}$. on two occasions (normal values 7-20 mg.), 17-hydroxysteroids of $5 \cdot 2 \mathrm{mg}$. (normal

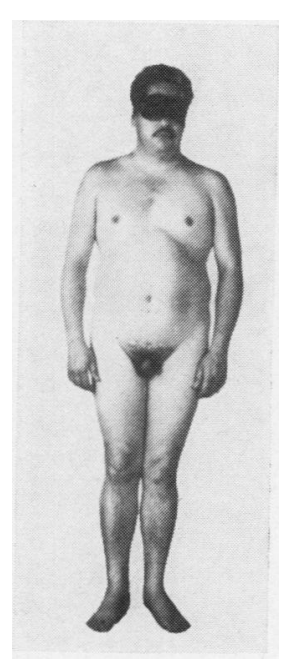

FIG. 1. Clinical photograph of the propositus. 


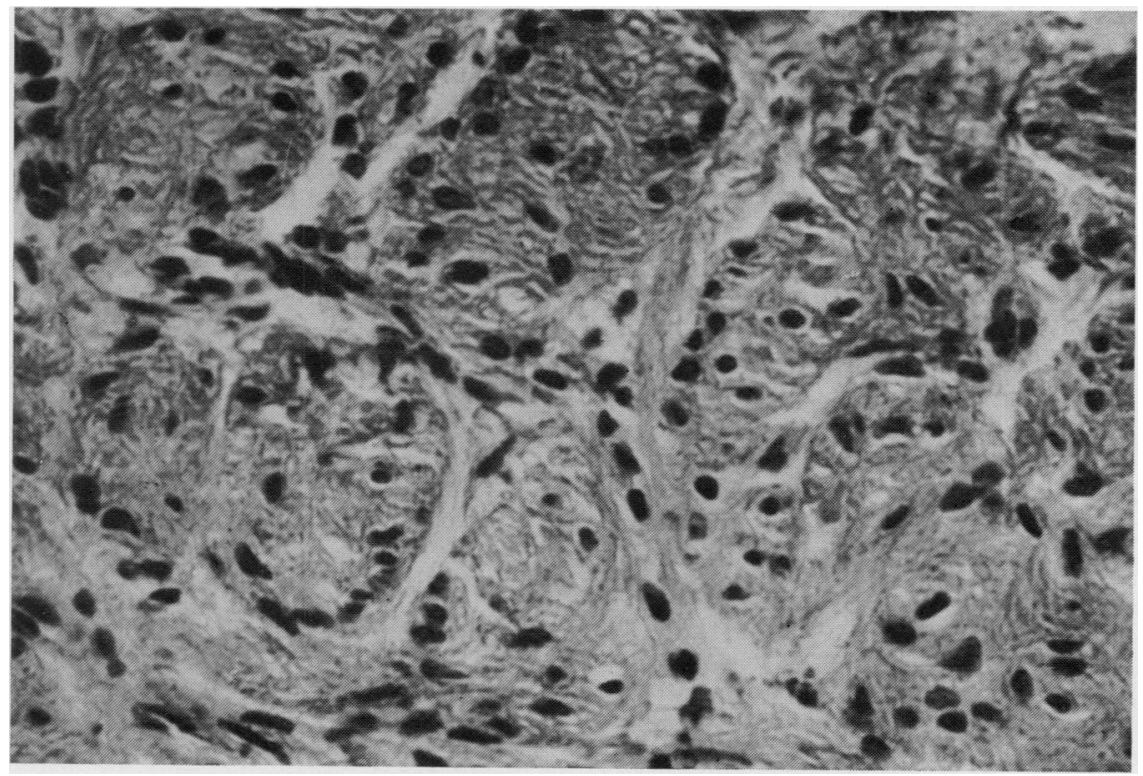

FIG. 2. Testicular biopsy showing diffuse interstitial fibrosis, tubular fibrosis, and azoospermia. $(\times 100$. $)$

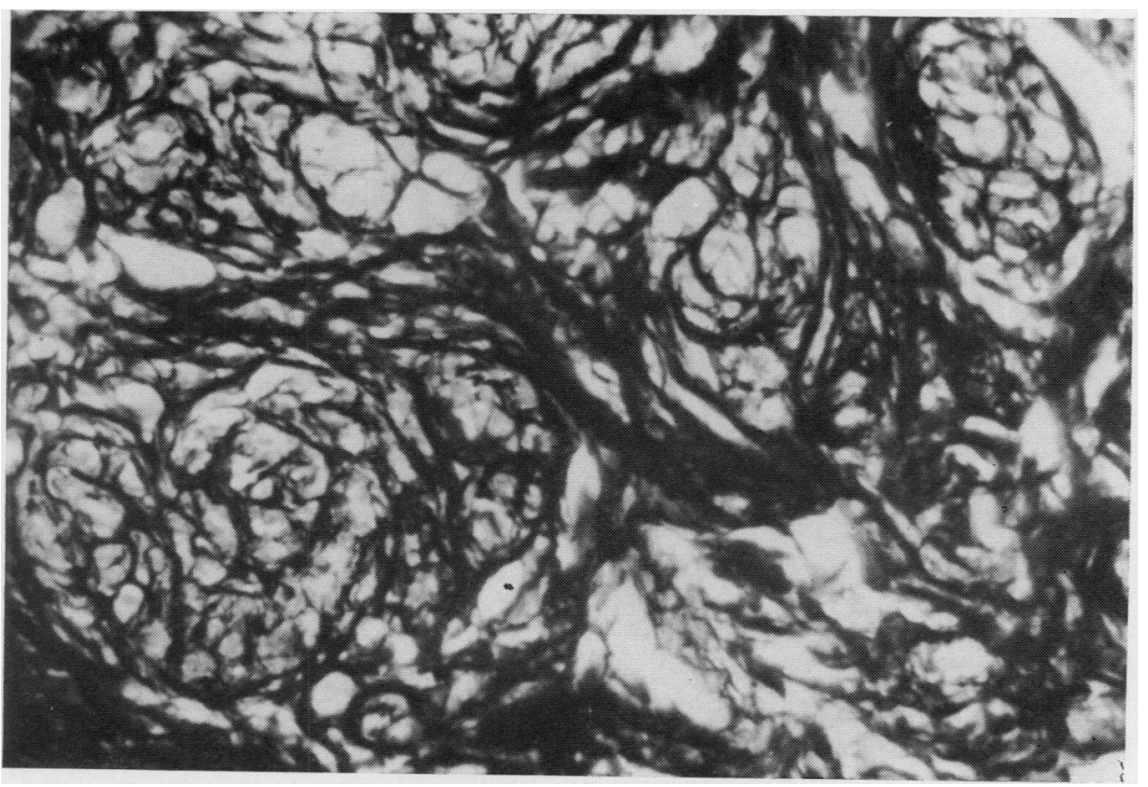

FIG. 3. High magnification of special silver stain of testicular biopsy. It shows clearly the obvious intratubular fibrosis. ( $\times 430$.) 
$3.4 \pm 1.7 \mathrm{mg}$.) and urinary gonadotrophins were 48 mouse units (normal 6-24 mouse units).

The presence of intra-abdominal female genitalia was ruled out by pneumopelvigraphy and peritoneoscopy.

The patient's father is dead and was 35 years old when the patient was born; his mother was 30 years old at his birth and is alive and well. He has 2 brothers, aged 33 and 39 years: both have a normal male phenotype and normal genitalia. The younger is single and the older has been married for several years but has no children. $\mathrm{Xg}^{\mathrm{a}}$ determinations were performed in the propositus who is negative and in his mother who is positive.

Dermatoglyphs and cytogenetic studies. The dermatoglyphic study revealed a low absolute ridge count of 38 (normal for Mexican population $149 \pm 49 \cdot 6$ (Zavala, Gonzáles, and Lisker, 1969)), having plain arches in digits 2, 3, and 4 of both hands. Digits 1 and 5 bilaterally show ulnar loops; $a-b$ ridge count of 83 ; atd angle of 84.5. The palmar $c$ triradius is absent in both hands, and this is seen only in $1.2 \%$ of normal Mexican males. A sex chromatin analysis was performed in epithelial cells obtained from the oral mucosa: $19 \%$ of them had Barr bodies (normal female in our laboratory $24 \pm 6$ ). Chromosome analysis was done on peripheral blood cultivated for 72 hours, stimulated with phytohaemagglutinin and in a direct bone-marrow preparation. In lymphocytes, 101 metaphase plates adequate for analysis were studied. All had 46 chromosomes, with only 4 chromosomes in the G group, and the karyotype of 7 cells showed a 46,XX complement (Fig. 4). In some of the cells all members of the $G$ group had satellites, thus proving that none is a $\mathrm{Y}$ chromosome. In the bonemarrow, only 18 cells were adequate for analysis, all had
46 chromosomes, G group composed of only 4 chromosomes, and the karyotype of 2 cells showed a normal female complement, 46,XX (Fig. 5).

Chromosome analysis in peripheral blood from the 2 brothers revealed a normal $46, \mathrm{XY}$ complement.

\section{Discussion}

The diagnosis of this individual as an $\mathrm{XX}$ male seems to be well established. $\mathrm{He}$ has a normal male phenotype, absence of intra-abdominal Müllerian organs, and a 46,XX chromosome complement in 2 tissues-lymphocytes and bonemarrow. The presence of Barr bodies in $19 \%$ of the epithelial cells studied also indicates the existence of two $\mathrm{X}$ chromosomes in this tissue. The possibility of mosaicism, with a few Y-containing cells in the tissues studied (as found by Hecht et al., 1966) or in other tissues, cannot be definitely ruled out, and must remain as a possibility.

Clinically, the patient is similar to those previously described, but differs from the other patients in two facts: (1) the hair growth is entirely normal, including that in the face, requiring daily shaving; this contrasts with the other cases which have poor facial hair development (Grouchy et al., 1967); (2) libido and sexual performance appear to be normal, whereas the rule is that they are diminished to variable degrees (Grouchy et al., 1967); this fact has made it possible for the patient to lead a normal life and not seek medical consultation in this regard.

The absence of gynaecomastia is a common finding, as all patients except those described by Court

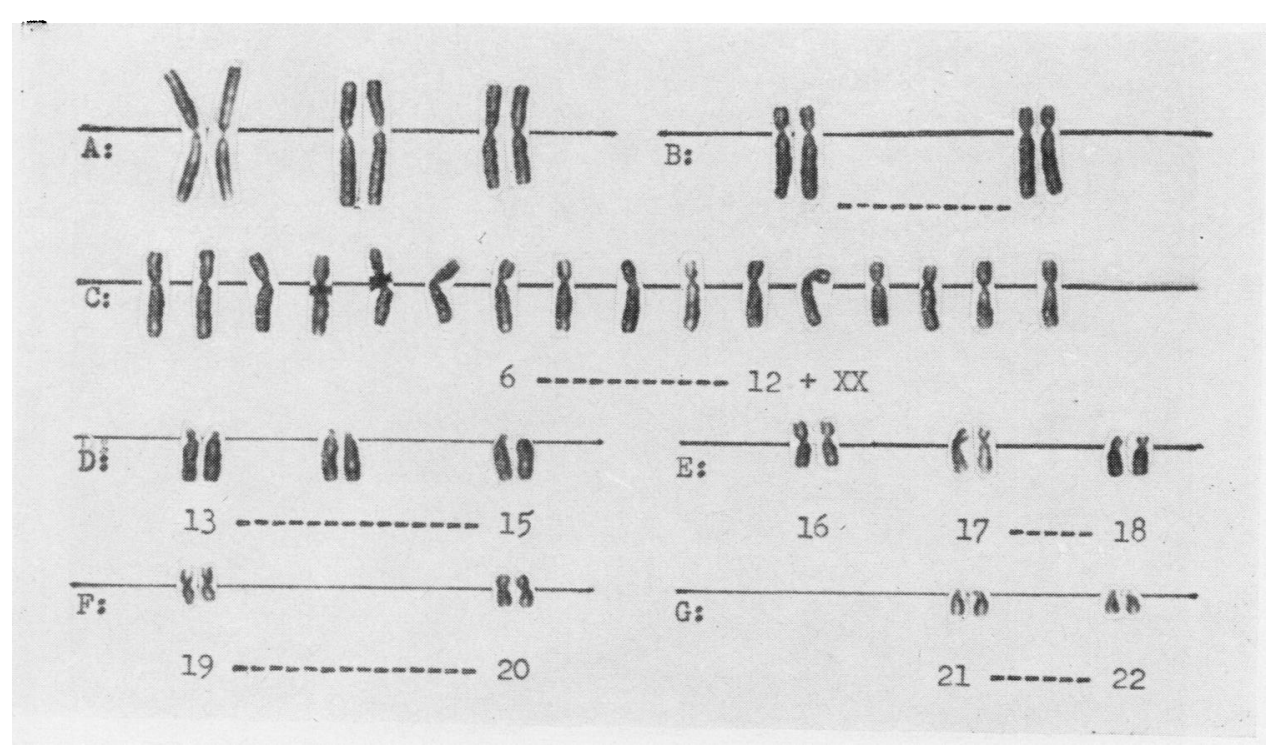

Fig. 4. Karyotype from a peripheral blood culture showing a 46,XX complement. 


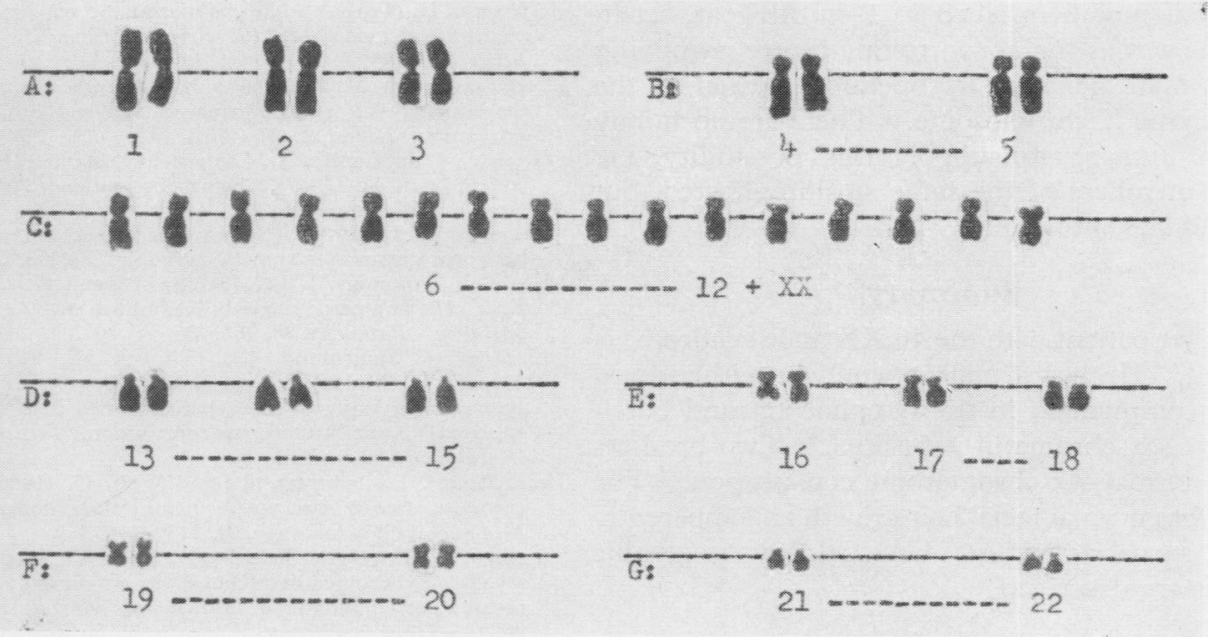

FIG. 5. Karyotype from a direct bone-marrow preparation, showing a $46, \mathrm{XX}$ complement.

Brown et al. (1964) and Strauch et al. (1965) have not had this abnormality. As far as intelligence is concerned, about half of the patients are said to be of normal intelligence (Grouchy et al., 1967), and this subject should be included in this group. On the other hand, small testicles with histological data similar to Klinefelter's syndrome have been described in all subjects, and they seem to be an essential finding to establish the diagnosis of the $\mathrm{XX}$ male syndrome. The hormonal investigations, in particular the gonadotrophins, have been reported normal in some instances and high in others. In our patient they were raised and would classify this case as a hypergonadotrophic hypogonadism, implying that there was no hypophysial abnormality.

Dermatoglyphic studies are available only in the 2 patients described by Grouchy et al. (1967). Both had, as an 'abnormal' finding, the presence of bilateral radial loops in the second digit. Our patient did not have this abnormality, but has two unusual features: a very low total ridge count and absence of the triradius $c$ in both hands. More patients will have to be analysed to learn if any distinctive dermatoglyphic pattern is present in this syndrome.

Regarding the question of testicular development without demonstrable $\mathrm{Y}$ chromosome, there are 3 main hypotheses to explain it: (1) the possibility already mentioned that these individuals are chromosomal mosaics, with a Y-containing cell line that is difficult to find evidence of. This possibility is unlikely, at least in patients in whom many cells from different tissues have been examined, but it cannot be ruled out completely; (2) de la Chapelle et al. (1965) believe that the zygote in these individuals starts with the XXY sex chromosome complement and initiates differentiation as males. During one of the early cell divisions in the embryo the $\mathrm{Y}$ chromosome is lost but sexual differentiation continues as initiated; (3) the paternal $\mathrm{X}$ chromosome in these subjects is not a normal one (FergusonSmith, 1966), but has some $Y$ material obtained through a reciprocal translocation between the $\mathrm{X}$ and $\mathrm{Y}$ chromosome occurring during meiosis $\mathrm{I}$, and thus the morphological $\mathrm{X}$ has enough $\mathrm{Y}$ material to cause testicular development.

The results of the $\mathbf{X g}^{\mathrm{a}}$ studies of de la Chapelle et al.'s patients (1965), which indicate that both $\mathrm{X}$ chromosomes in his propositi are of maternal origin, would go along with but does not prove his idea. In our family, the $\mathrm{Xg}^{\mathrm{a}}$ data are not informative. The mother is positive, the father not available, and the propositus negative. This means that the mother is heterozygous and that both $\mathrm{X}$ chromosomes in the propositus could be maternal or one could come from each parent, if the father was also negative.

Lastly, the possibility that this is not a chromosomal abnormality, but the result of a gene mutation should also be considered. In the goat, the autosomal dominant gene which controls horn growth (P) causes testicular development in homozygous (PP) females and something similar has been described in pigs (for review see Hamerton, 1968). This author has suggested that normally in the short arms of the $\mathrm{Y}$ chromosome there exists a 'controlling centre' for the structural gene for gonadal medullary stimulation, and suggests that 
autosomal modifiers, such as $\mathbf{P}$ in the goat, act in the same way as the $Y$ controlling centre, switching on the male gene or its operator located in the euchromatic $\mathrm{X}$ chromosome. There are no family data in humans to support this possibility, i.e. several members of the same sibship affected, but it should be kept in mind.

\section{Summary}

Another patient with the $46, \mathrm{XX}$ male syndrome is reported. He has a male phenotype with proved $46, \mathrm{XX}$ complement in the lymphocytes and bonemarrow; sex chromatin is positive. Two brothers have a normal sex chromosome constitution. The patient has normal facial hair growth and apparently normal sexual activities. Unusual dermatoglyphic findings are described.

\section{REFERENCES}

de la Chapelle, A., Hortling, H., Niemi, M., and Wennström, J. (1964). XX sex chromosomes in a human male. First case. Acta Medica Scandinavica, Suppl., 412, 25-38.

- — - Wennström, J., Niemi, M., and Johansson, C. (1965). Two males with female chromosomes. Acta Endocrinologica (København), Suppl., 100, 90.

Court Brown, W., Harnden, D., Jacobs, P., Maclean, N., and
Mantle, D. (1964). Abnormalities of the sex chromosome complement in man. Medical Research Council. Special Report Series, No. 305.

Ferguson-Smith, M. A. (1966). X-Y Chromosomal interchange in the aetiology of true hermaphroditism and of XX Klinefelter syndrome. Lancet, 2, 475-476.

Grouchy, J. de, Canivet, J., Canlorbe, P., Mantel, O., Borniche, P., $\mathscr{\mathcal { A }}$ and Poitout, M. (1967). Deux observations d'hommes 46,XX. Annales de Génétique, 10, 193-200.

Hamerton, J. L. (1968). Significance of sex chromosome derived heterochromatin in mammals. Nature (London), 219, 910-914.

Hecht, F., Antonius, J. I., McGuire, P., and Hale, C. G. (1966). XXY cells in a predominantly XX human male: evidence for cell selection. Pediatrics, 38, 982-985.

Lindsten, J., Bergstrand, C., Tillinger, K., Schwarzacher, H., Tiepolo, L., Muldal, S., and Hokfelt, B. (1966). A clinical and $\overrightarrow{0}$ cytogenetical study of three patients with male phenotype and apparent XX sex chromosome constitution. Acta Endocrinologica (Kobenhavn), 52, 91-112.

von Mulert, L., Schröter, R., and Wolf, U. (1966). Weiblicher chromosomensatz bei einem mann ohne hodentubuli Dtsch. Medizinische Wochenschrift, 91, 2159-2165.

Strauch, G., Engel, E., Taft, P. D., Atkins, L., and Forbes, A. D. V (1965). Syndrome de Klinefelter à caryotype $46 / \mathrm{XX}$ aux niveaux cutané, sanguin et testiculaire. Annales d'Endocrinologie, 26, 727-738.

Therkelsen, A. (1964). Sterile male with the chromosome constitution 46,XX. Cytogenetics, 3, 207-215.

Zavala, C., Gonzáles, G., and Lisker, R. (1969). Dermatoglyphic patterns in a sample of normal urban Mexicans. Human Heredity, 19, 534-539.

Zuppinger, K., Engel, E., Forbes, A. P., Mantooth, L., and Claffey, J. (1967). Klinefelter's syndrome, a clinical and cytogenetic study in 24 cases. Acta Endocrinologica (København), Suppl., 113, 5-48. 